Ramelan, Eman, 2008, "Asas Pemisahan Horizontal dalam Hukum Tanah Nasional," Pidato Pengukuhan, Guru Besar Ilmu Hukum Agraria Universitas Airlangga.

Ramulyo, Mohd. Idris, 2006, Hukum Perkawinan, Hukum Kewarisan, Hukum Acara Peradilan Agama, dan zakat menurut hukum Islam, Sinar Grafika, Jakarta.

Simanjuntak, 2009, Pokok-Pokok Hukum Perdata Indonesia, Djambatan, Jakarta.

Soemitro, Ronny Hanitijo, 2008, Metode Penelitian Hukum dan Jurimetri, Alumni, Jakarta.

Subekti, 1995, Pokok-pokok Hukum Perdata, Cetakan XXVII, Internusa, Jakarta.

Sumardjono, Maria S.W., 2010, Kebijakan Pertanahan: Antara Regulasi dan Implementasi, Kompas, Jakarta.

Susanto, Happy, 2008, Pembagian harta gono-gini saat terjadi perceraiaan, Visimedia, Jakarta.

Syarifuddin, Amir, 2009, Hukum Perkawinan Islam di Indonesia, Kencana, Jakarta

$* * * * *$

Acta Comitas (2017) $1: 57-65$

ISSN : 2502-8960 I e-ISSN : 2502-7573

\title{
KUASA MENJUAL NOTARIIL SEBAgAi INSTRUMEN PEMENUHAN KEWAJIBAN DEBITUR YANG WANPRESTASI DALAM PERJANJIAN UTANG PIUTANG
}

Oleh :

\author{
Gede Dicka Prasminda* Yohanes Usfunan**, I Made Udiana*** \\ Mahasiswa Program Magister Kenotariatan Universitas Udayana \\ Email : dickaprasminda@gmail.com
}

\begin{abstract}
The granting of power of attorney to sell the land rights as an instrument for the fulfillment of the obligations of the debtor in a loan agreement of a notarial deed may commonly be found in the everyday practice of the notaries. Power of Attorney to sell is used by the proxy to sell the land of the authorizer in the event that the authorizer (debtor) experienced defaults. The Civil Law Code and the Law No. 4 of 1996 on Mortgage do not stipulate the power attorney to sell as an instrument in the loan agreement.

There are two legal contents analyzed from the vacancy of norms regarding the power of attorney to sell, namely: (1) how the arrangement of power of attorney to sell of the land rights as an instrument for the fulfillment of obligations on the loan agreement in the legislation on the guarantee law and (2) the legal effect of power of attorney to sell the land rights as an instrument for the fulfillment of obligations of the debtor in case of default under the loan agreements in connection with the execution of the law of guarantee. The type of research used in this thesis is a normative legal research with the statutory, concept and case approaches.

Based on the research results, it was revealed that the power of attorney to sell is based on the agreement of the parties which make the basis of the principle of freedom of contract. The Power of Attorney Deed shall be valid unless otherwise it is canceled by the judge with a court ruling that has the binding legal force. The use the deed of power of attorney to sell is considered weak because the power of attorney to sell can not be used as a basis for executing security object between the grantor and the recipient of the power of attorney.

Deed of power of attorney to sell is deemed not obtain legal certainty because at the time of registration of transfer of land rights, the power of attorney to sell can not be accepted by the local Land Registry Office. Responsibility for the grantor and the recipient of power of attorney is related to the obligations and rights of the grantor and the recipient of the power of attorney. As for the responsibility of the notary who made the deed of power of attorney to sell can be studied from three aspects, namely: (1). Civil responsibility; (2). Administrative responsibility; and (3). Criminal responsibility. Legal remedies that can be taken if the debtor is experiencing defaults can be done by way of a summons in advance without selling
\end{abstract}


the rights of the land owned by the grantor of the power of attorney to sell (the debitor).

Keywords: Power of Attorney to Sell, Land Rights, Default, Debt.

\author{
* Mahasiswa Program Studi Magister Kenotariatan T.A 2015/2016 \\ ** Pembimbing I \\ *** Pembimbing II
}

\section{B AB I \\ PENDAHULUAN}

\subsection{Latar Belakang Masalah}

Pemberian kuasa menjual hak atas tanah sebagai instrumen pemenuhan kewajiban debitur dalam suatu perjanjian utang piutang dalam bentuk akta notariil sebagaimana pembahasan dalam proposal tesis ini masih dapat ditemui dalam praktik kenotariatan sehari-hari.Pemberian kuasa menjual tersebut menurut penulis perlu kajian yuridis lebih lanjut, sebab pemberian kuasa tersebut kurang tepat karena alasan-alasan antara lain:

I. Untuk menjaminkan hak atas tanah sebagai jaminan pelunasan utang debitur sudah ada lembaga jaminan yaitu Hak Tanggungan, sehingga tidak perlu lagi kuasa menjual untuk menjamin pelunasan utang debitur;

II. Pembuatan akta kuasa menjual sebagai instrument pemenuhan kewajiban debitur sangat beresiko karena merugikan debitur itu sendiri, mengingat dengan akta kuasa menjual maka setiap saat kreditur dapat menjual obyek yang dijaminkan oleh debitur. Dengan demikian maka tidak ada perlindungan hukum bagi debitur untuk mempertahan haknya. Meskipun debitur telah menjaminkan hak atas tanah yang dimilikinya bukan berarti hak tersebut telah beralih kepada kreditur;

III. Perjanjian utang piutang yang diikuti dengan pemberian kuasa menjual bertentangan dengan asas kepentingan umum sebab penjualan benda jaminan harus dilakukan secara sukarela atau dimuka umum melalui lelang. Sehingga pemberian kuasa semacam ini adalah batal demi hukum. Mengenai penjualan bawah tangan sudah diatur pula didalam Pasal 20 Undang-Undang Hak Tanggungan, apabila pelaksanaan penjualan secara bawah tangan tidak sesuai dengan yang ada dalam Pasal tersebut dinyatakan batal demi hukum.

IV. Apabila dilihat dari konstruksi hukum dalam pemberian kuasa ini adalah apabila debitur wanprestasi, maka kreditur berdasarkan kuasa jual yang telah diberikan kepadanya akan menjual obyek jaminan tersebut untuk mengambil pelunasan piutangnya. Dalam konteks ini kuasa yang diberikan seperti kuasa mutlak yang tidak dapat ditarik kembali oleh si pemberi kuasa, yang mana kuasa tersebut dilarang berdasarkan Instruksi Menteri Dalam Negeri Nomor 14 Tahun 1982 Tentang
Larangan Penggunaan Kuasa Mutlak Sebagai Pemindahan Hak Atas Tanah.

Dari keempat alasan kurang tepatnya pemberian kuasa menjual dalam perjanjian utangpiutang menunjukkan bahwa kuasa menjual yang dipakai oleh para pihak tidak mempunyai kepastian hukum karena tidak bermanfaat bagi salah satu pihak.Kurang bermanfaatnya kuasa menjual tersebut akibat tidak adanya perlindungan hukum terhadap para pihak dalam membuat perjanjian utang-piutang tersebut. Dengan kata lain, pihak kreditur dirugikan haknya karena kedudukan kreditur menjadi kreditur konkuren yang berarti pemberi kredit tidak didahulukan hak-haknya dari kreditur lainnya sedangkan pihak debitur dirugikan jika jaminan yang berupa hak atas tanah menjadi beralih haknya walaupun debitur tidak wanprestasi.

Bertitik tolak dari penjelasan diatas maka terdapat kekosongan norma di dalam penelitian ini. Kekosongan norma ini terjadi karena tidak adanya suatu peraturan perundang-undangan yang mengatur tentang pengertian kuasa menjual, tata cara pemberian kuasa menjual dan akibat yang ditimbulkan dari kuasa menjual tersebut. Ketentuan tersebut yang menyebabkan perlu adanya pengaturan lebih jelas mengenai kuasa menjual sehingga para pihak yang membuat kuasa menjual dapat dilindungi hak-haknya.

\subsection{Rumusan Masalah}

1. Bagaimana pengaturan pemberian kuasa menjual hak atas tanah sebagai instrumenpemenuhan kewajiban atas perjanjian utang piutang dalam peraturan perundang-undangan tentang hukum jaminan?

2. Apakah akibat hukum dari pemberian kuasa menjual hak atas tanah sebagai instrumen pemenuhan kewajiban debitur yang wanprestasi dalam perjanjian utang piutang dalam kaitannya dengan pelaksanaan eksekusi jaminan?

\subsection{Metode Penelitian}

Jenis Penelitian yang dilakukan dalam tesis ini merupakan penelitian hukum normatif. Penelitian hukum normatif yang mengacu pada bahan hukum primer dan bahan hukum sekunder serta bahan hukum tertier. Dalam penelitian ini, penulis menggunakan beberapa jenis pendekatan untuk menganalisis permasalahan yang ada, yaitu : (1). Pendekatan Perundang-Undangan (The Statute Approach), (2). Pendekatan Konsep Hukum (Conceptual Approach). 
Adapun tahapan analisis dalam penelitian ini, yaitu dengan cara bahan-bahan hukum yang telah dikumpulkan kemudian dilanjutkan dengan proses analisis, yaitu menganalisis bahan-bahan yang terkumpul dengan menggunakan beberapa teknik yaitu teknik deskripsi, sistematisasi, dan evaluasi lalu disimpulkan dengan teknik argumentasi.

\section{Pembahasan}

\subsection{Pengaturan Pemberian Kuasa Menjual Hak Atas Tanah Dalam Perjanjian Utang Piutang}

\subsubsection{Pengaturan Pemberian Kuasa} Menjual Hak Atas Tanah

Kuasa memang sangat dibutuhkan dalam kehidupan masyarakat yang serba komplek ini, untuk memudahkan seseorang yang secara langsung tidak dapat melaksanakan hak dan kewajibannya dalam lalu lintas hukum, dikarenakan terbatasnya waktu, jauhnya jarak, keadaan fisik, keadaan sosial ekonomi dan lainnya, dapat dilakukan dengan menggunakan kuasa yang diatur dalam pasal 1792 sampai dengan pasal 1819 KUHPerdata Indonesia.

Prinsip-prinsip hukum dalam "pemberian kuasa" yang bersumber dari KUHPerdata (Pasal 1792 sampai dengan 1819). Suatu pemberian kuasa mempunyai batasan-batasan yang wajib ditaati oleh pemberi kuasa dan penerima kuasa. Batasan-batasan yang menjadi acuan dalam pembuatan akta-akta kuasa yaitu:

1. Larangan Penerima Kuasa Sebagai Pembeli (Selbsteintritt) yang tercantum dalam Pasal 1470 KUHPerdata

2. Larangan Penggunaan Kuasa Mutlak atas Objek Hak atas Tanah

3. Kuasa Dengan Klausula Tidak Dapat dicabut Kembali

4. Kuasa Dengan Hak Substitusi

5. Kuasa Kepada Lebih Dari Satu Penerima Kuasa

Dari kelima jenis pembuatan akta-akta kuasa diatas maka penulis dapat simpulkan bahwa konstruksi pembuatan kuasa dikaji dari 2 (dua) konsep, yaitu konsep volmacht dan konsep lastgeving sebagai pemberian kuasa. Pembuatan akta-akta kuasa notariil harus berdasarkan bentuk yang diatur dalam UUJN Perubahan sedangkan untuk substansi kuasa diatur dalam ketentuan Pasal 1792 s/d 1819 KUHPerdata. Dalam Kuasa dikenal adanya asas nemo plus iuris ad alium transferre potest quam ipse haberet (asas nemo plus iuris) yaitu suatu asas yang menyatakan bahwa seseorang tidak dapat mengalihkan hak kepada orang lain lebih dari pada hak yang dimilikinya atau pemberi kuasa tidak dapat memberikan kuasa lebih dari pada hak atau kewenangan yang dimilikinya. Contoh harta warisan yang merupakan harta bersama yang terikat, menjadi hak dan kewenangan segenap ahli waris, setiap ahli waris tidak berwenang untuk melakukan perbuatan hukum atas harta warisan yang menjadi bagian atau haknya kecuali telah terlebih dahulu dilakukan pembagian dan pemisahan harta warisan (boedel waris) diantara para ahli waris.Akibat hukum dari ketidakwenangan adalah bahwa perbuatan hukum yang dilakukan oleh penerima kuasa batal demi hukum.

Secara normatif, ketentuan yang mengatur mengenai kuasa menjual tidak ditemukan di dalam berbegai ketentuan peraturan perundangundangan.Hal ini mengakibatkan terdapat ruang yang bebas untuk membuat perjanjian kuasa menjual tersebut.Para pihak yang membuat kuasa menjual tersebut biasanya berdalil dengan alasan asas kebebasan berkontrak, sehingga akibat dari tidak adanya pengaturan mengenai kuasa menjual dapat merugikan berbagai pihak termasuk notaris sendiri.

Ketentuan-ketentuan di dalam KUHPerdata belum mencukupi untuk memenuhi kebutuhan masyarakat akan hukum. Perbuatan-perbuatan hukum yang dilakukan oleh masyarakat akan berkembang seiring dengan berkembangnya jaman. Hal ini perlu diakomodir dengan ketentuan peraturan perundang-undangan yang perlu di updatekarena masih banyak perbuatan-perbuatan hukum yang tidak ada paying hukumnya.

\subsubsection{Keabsahan Kuasa Menjual Hak Atas Tanah dalam Perjanjian Utang Piutang \\ Dalam kaitannya dengan fungsi kuasa} menjual dalam perjanjian utang piutang ini, bahwa pada dasarnya kegunaan kuasa ini bagi debitur adalah untuk menjamin pelunasan hutangnya kepada kreditur.Sedangkan bagi kreditur adalah sebagai alat untuk menjual atau mengalihkan kepemilikan hak atas tanah yang menjadi objek jaminan untuk mendapatkan pelunasan hutang debitor. Namun dalam praktik penjualan objek jaminan apabila debitur wanprestasi dilakukan setelah debitur membuat dan menandatangani penyerahan sukarela yang berisikan bahwa debitor sama sekali tidak keberatan untuk dijual tanah yang menjadi objek jaminan apabila debitor wanprestasi atau cidera janji dengan syarat apabila terjadi kelebihan harga dari objek jaminan maka kelebihan harga tersebut dikembalikan kepada debitor.

Fungsi kuasa menjual ini menjadi tidak berarti apabila kuasa menjual itu bersama-sama/ disandingkan dengan Hak Tanggungan yang mempunyai titel eksekutorial. Apabila terjadi debitor wanprestasi dan objek jaminan akan dieksekusi maka secara hukum yang digunakan adalah Sertifikat Hak Tanggungan yang mempunyai irah-irah "Demi Keadilan Berdasarkan Ketuhanan Yang Maha Esa." Lain halnya jika para pihak sepakat dan setuju untuk menjual objek jaminan itu secara dibawah tangan dengan ketentuan asal mencapai harga yang 
tertinggi dan menguntungkan kedua belah pihak. Kuasa menjual akan berfungsi dengan baik dan dapat menguntungkan para pihak apabila dilaksanakan sebagaimana tersebut di atas.

Keuntungan-keuntungan yang diperoleh dalam pembuatan kuasa menjual hak atas dalam perjanjian utang piutang, yaitu :

1. Dalam hal wanprestasi, kedudukan kreditur diuntungkan karena proses penjualan terhadap hak atas tanah tersebut tanpa menggunakan pengumuman 2 (dua) media massa atau surat kabaryang berfungsi untuk memenuhi asas publisitas dalam penjualan objek jaminan tersebut (Pasal 20 ayat 3 UUHT).

2. Pembuatan kuasa menjual hak atas tanah ini tidak perlu didaftarkan di Kantor Pertanahan karena pengaturan kuasa menjual harus didaftarkan tidak ditemukan di berbagai ketentuan peraturan perundang-undangan hak atas tanah sehingga kreditur dan debitur dapat menghemat biaya tanpa perlu mendaftarkan Akta Pemberian Hak Tanggungan.

3. Prosedur pencairan uang atau kredit dianggap lebih cepat oleh para pihak ketika debitur memerlukan uang dalam waktu yang cepat. Dengan kata lain, proses pencairan uang dari kreditur ke debitur akan lebih cepat jika menggunakan kuasa menjual tersebut.

Sedangkan kerugian-kerugian yang didapat bila menggunakan kuasa menjual hak atas tanah dalam perjanjian utang piutang, yaitu :

1. Bagi pihak debitur yang tidak wanprestasi atau cidera janji dapat kehilangan hak atas tanahnya karena kreditur dapat menjual hak atas tanah tersebut tanpa sepengetahuan debitur.

2. Bagi pihak kreditur yang membuat kuasa menjual dapat menjadi kreditur konkuren yang mana hak atas tanah tersebut dijaminkan lagi oleh debitur dengan pihak ketiga tanpa sepengetahuan kreditur. Hal ini sesuai dengan Penjelasan UUHT angka 8 yang menyatakan kedudukan kreditur setelah didaftarkan di Kantor Pertanahan yang diutamakan terhadap krediturkreditur lainnya. Dengan kata lain kreditur yang membuat kuasa menjual hak atas tanah akan menjadi kreditur konkuren tidak kreditur preferen.

Fungsi kuasa menjual pada dasarnya adalah untuk menjamin pelunasan utang debitor, dalam arti kreditor sangat berkepentingan untuk mengambil pelunasan hutang tersebut untuk memperkecil atau mengurangi kerugian bahkan mencegah kerugian dalam menyalurkan kredit; dan memberikan kepastian hukum dan perlindungan hukum bagi keamanan kreditor.

Adapun susunan dan anatomi dari akta kuasa menjual jika ditelaah sesuai dengan ketentuan Pasal 36 UUJN Perubahan adalah sebagai berikut :

1. Kepala atau Judul; “Kuasa Menjual ", menggambarkan mengenai isi atau jenis kesepakatan yang disepakati oleh para pihak. Dengan adanya judul atau kepala yang jelas dan tegas dapat menghindari adanya penafsiran terhadap kesepakatan termaksud.Kepala atau judul harus sesuai dengan isinya.

2. Badan akta memuat :

a. Nomor akta, Jam/Pukul, tanggal, bulan dan tahun penandatanganan serta tempat kedudukan Notaris; penulisan Jam/Pukul, tanggal, bulan dan tahun penandatanganan serta tempat kedudukan Notaris pada satu akta (perjanjian kuasa) mutlak adanya dan diletakkan pada bagian awal. Hal ini sangat perlu dalam kaitannya dengan keabsahan kapasitas para pihak dan keabsahan dari kesepakatan yang telah dicapai.

b. Komparisi (identitas para pihak); (kreditor dan debitor). Pada bagian ini juga harus tergambar dengan jelas dan tegas mengenai kecakapan atau kewenangan dari para pihak dalam bertindak, serta kapasitasnya dalam bertindak (kapasitas pribadi, mewakili badan hukum atau mewakili orang lain lain ataukah mewakili jabatan).

c. Premis; bagian ini penting untuk di tuangkan dalam akta (perjanjian kuasa), karena dengan adanya premis pembaca dapat dengan mudah memahami alasan, dasar, maksud dan tujuan dilakukan/diadakannya akta (perjanjian kuasa) serta untuk memperjelas kepala/judul kontrak/perjanjian serta memudahkan para pihak atau orang lain menafsirkan isi perjanjian apabila terjadi perselisihan.

d. Isi akta (kuasa menjual) yang biasanya memuat pasal-pasal yang bertujuan untuk mengatur hak dan kewajiban para pihak, 
apa yang harus dilaksanakan dan apa yang tidak boleh dilaksanakan. Pada bagian ini diatur mengenai unsur esensialia, naturalia bahkan aksidentalia. Apabila ditelaah dan dianalisis isi dari kuasa menjual tersebut, diperoleh gambaran bahwa kuasa menjual tersebut benar-benar merupakan pelimpahan wewenang dan kekuasaan dari debitor kepada kreditor untuk mengalihkan hak atas tanahnya baik kepada orang lain maupun kepada diri kreditor sendiri apabila debitor wanprestasi atau cidera janji. Pelimpahan wewenang atau kekuasaan untuk mengalihkan hak atas tanah tersebut disebutkan secara jelas dan tegas mengenai objeknya dan merupakan satu kesatuan yang tidak dapat dipisahkan dengan Perjanjian Kredit yang telah ditandatangani terlebih dahulu oleh kedua belah pihak. Apabila mengacu pada kuasa tersebut, kreditor tidak perlu meminta lagi penyerahan sukaralea dari debitor apabila kreditor akan menjual objek jaminan pada saat debitor wanprestasi atau cidera janji.

3. Penutup akta (perjanjian kuasa); pada bagian ini menjelaskan bahwa akta (perjanjian kuasa) termaksud dibuat dan ditandatangani serta diselesaikan pada tempat, tanggal dan bulan serta tahun. Selain itu juga diatur mengenai keberlakuannya satu akta (perjanjian kuasa) yang dibuat dan ditandatangani.

Pada dasarnya pengaturan penjualan objek jaminan itu sama saja baik melalui Hak Tanggungan maupun kuasa menjual, keduanya mensyaratkan adanya kesepakatan para pihak apabila dengan cara itu akan memperoleh harga yang tertinggi yang menguntungkan kedua belah pihak. Keabsahan kuasa menjual hak atas tanah merupakan sah bagi para pihak yang membuatnya sepanjang para pihak tidak mempermasalahkan perjanjian kuasa menjual tersebut.Hal ini sejalan dengan konsep hukum administrasi negara yang mana suatu tindakan pemerintah selalu dianggap sah (rechmatig) sampai ada pembatalannya (asas vermoeden van rechmatigheid / praesumptio iustae causa). ${ }^{1}$

${ }^{1}$ Philipus $\quad$ M. Hadjon, 1983, (Bestuurshandeling) Tindak Pemerintahan : Pengertian-Pengertian Dasar, Djumali, Surabaya, hal. 5 .
Asas praduga keabasahan (vermoeden van rechtmatigheid/presumtio iusta causa), ${ }^{2}$ suatu KTUN hanya dapat dibatalkan (vernietigbaar) dan bukan batal (nietig) atau batal demi hukum (nietig van rechtwege). ${ }^{3}$ Menurut penulis KTUN selalu tidak boleh dianggap batal demi hukum (nietig van rechtwege). KTUN tidak pernah boleh dianggap batal demi hukum, baik dalam hal keputusan itu dapat digugat di muka hakim administrasi/PTUN atau banding administrasi (administratiefberoef), maupun dalam hal kemungkinan untuk menggugat dan untuk memohon banding itu tidak digunakan, demikian juga dalam hal kedua kemungkinan tersebut tidak ada. Untuk KTUN yang dapat dibatalkan (vernietigbaar), perbuatan hukum dianggap sah sampai dinyatakan batal.KTUN yang dapat dibatalkan yaitu KTUN yang mengandung cacat.Selama pihak yang berkepentingan dengan pembatalan itu tidak pernah menyatakan bahwa karena cacat hukum tersebut KTUN itu dipandang sebagai tidak sah (onrechtmatig), maka tidak dapat dikatakan adanya pembatalan (vernietiging).

\subsection{Akibat Hukum Pemberian Kuasa Menjual Hak Atas Tanah Sebagai Instrumen Pemenuhan Kewajiban Debitur Yang Wanprestasi Dalam Perjanjian Utang Piutang \\ 2.2.1. Tanggung Jawab Pemberi dan Penerima Kuasa dalam Akta Kuasa Menjual yang Dibuat Dihadapan Notaris}

Rumusan dalam Pasal 1234 KUHPerdata, menyebutkan bahwa "tiap-tiap perikatan adalah untuk memberikan sesuatu, untuk berbuat sesuatu, atau untuk tidak berbuat sesuatu", maka dapat dikemukakan bahwa isi pasal tersebut sangat menekankan pada kewajiban pemenuhan perikatan, yang dikelompokkan menjadi 3 (tiga) macam, yaitu dalam bentuk kewajiban untuk memberikan sesuatu, melakukan sesuatu dan atau untuk tidak melakukan sesuatu.

Pentingnya penentuan kewajiban yang harus dipenuhi oleh pihak yang berkewajiban. Kewajiban untuk memberikan sesuatu, melakukan sesuatu, dan atau untuk tidak melakukan sesuatu tersebut disebut dengan prestasi. Prestasi untuk melaksanakan kewajiban tersebut di atas memiliki 2 (dua) unsur penting, yaitu :

Pertama, berhubungan dengan persoalan tanggung jawab hukum atas pelaksanaan

2 Ridwan HR, 2002, Hukum Administrasi Negara, Raja Grafindo Persada, Jakarta, hal. 255.

${ }^{3}$ Utrecht dan Moh. Saleh Djindang, 1990, Pengantar Hukum Administrasi Negara Indonesia, Ichtiar, Jakarta, hal. 82. 
prestasi tersebut oleh pihak yang berkewajiban.

Kedua berkaitan

dengan tanggungjawab pemenuhan kewajiban dari harta kekayaan pihak yang berkewajiban tersebut, tanpa memperhatikan siapa yang berkewajiban untuk memenuhi kewajiban tersebut. Sebaliknya kalau debitur tidak memenuhi prestasi, maka dikenal sebagai wanprestasi.

Mengenai tanggung jawab pemberi kuasa terdapat beberapa sifat pokok yang dianggap penting, antara lain sebagai berikut:

1) Penerima Kuasa langsung berkapasitas sebagai Wakil Pemberi

Kuasa

Pemberian kuasa tidak hanya bersifat mengatur hubungan internal antara pemberi kuasa dan penerima kuasa. Akan tetapi, hubungan hukum itu langsung menerbitkan dan memberi kedudukan serta kapasitas kepada kuasa menjadi wakil penuh (full power) pemberi kuasa, yaitu:

a) Memberi hak dan kewenangan (authority) kepada kuasa, bertindak untuk dan atas nama pemberi kuasa terhadap pihak ketiga;

b) Tindakan kuasa tersebut langsung mengikat kepada diri pemberi kuasa, sepanjang tindakan yang dilakukan kuasa tidak melampaui batas kewenangan yang dilimpahkan pemberi kuasa kepadanya;

c) Dalam ikatan hubungan hukum yang dilakukan kuasa dengan pihak ketiga, pemberi kuasa berkedudukan sebagai pihak materiil atau principal atau pihak utama, dan penerima kuasa berkedudukan dan berkapasitas sebagai pihak formil.

Akibat hukum dari hubungan yang demikian segala tindakan yang dilakukan kuasa kepada pihak ketiga dalam kedudukannya sebagai pihak formil, mengikat kepada pemberi kuasa sebagai prinsipal (pihak materiil).

2) Pemberi Kuasa bersifat Konsensual Sifat perjanjian atau persetujuan kuasa adalah konsensual (consensuale overeenkomst) yaitu perjanjian berdasarkan kesepakatan (agreement) dalam arti:

a) Hubungan pemberian kuasa, bersifat partai yang terdiri dari pemberi dan penerima kuasa; b) Hubungan hukum itu dituangkan dalam perjanjian pemberian kuasa, berkekuatan mengikat sebagai persetujuan di antara mereka (kedua belah pihak);

c) Oleh karena itu, pemberian kuasa harus dilakukan berdasarkan pernyataan kehendak yang tegas dari kedua belah pihak.

Itu sebabnya Pasal 1792 maupun Pasal 1793 ayat (1) KUH Perdata menyatakan pemberian kuasa selain didasarkan atas persetujuan kedua belah pihak, dapat dituangkan dalam bentuk akta otentik atau di bawah tangan maupun dengan lisan. Namun demikian tanpa mengurangi penjelasan di atas, berdasarkan Pasal 1793 ayat (2) KUH Perdata, penerimaan kuasa dapat terjadi secara diam-diam dan hal itu dapat disimpulkan dari pelaksanaan kuasa itu oleh pemberi kuasa. Akan tetapi, cara diam-diam ini, tidak dapat diterapkan dalam pemberian kuasa khusus.

3) Berkarakter Garansi Kontrak Ukuran untuk menentukan kekuatan mengikat tindakan kuasa kepada prinsipal (pemberi kuasa), hanya terbatas:

a) Sepanjang kewenangan (volmacht) atau mandat yang diberikan oleh pemberi kuasa;

b) Apabila kuasa bertindak melampaui batas mandat, tanggung jawab pemberi kuasa hanya sepanjang tindakan, yang sesuai dengan mandat yang diberikan. Sedang pelampauan itu menjadi tanggung jawab kuasa, sesuai dengan asas "garansi kontrak" yang digariskan Pasal 1806 KUH Perdata.

Analisis terhadap kewajiban pemberi kuasa dan penerima kuasa dalam akta kuasa menjual yang dibuat dihadapan notaris, yang tercantum dalam premis akta tertulis dengan rumusan kalimat sebagai berikut :

1. Kewajiban Pemberi Kuasa

Menyerahkan segala dokumendokumen yang berkaitan dengan benda sebagaimana disebutkan dalam butir 1 (satu) tersebut diatas kepada pembeli apabila seluruh kewajibankewajiban pembeli dalam jual beli tersebut diatas telah selesai dilaksanakan -.-.--.-.-.-.--

2. Kewajiban Penerima Kuasa

2.1. Untuk keperluan penjualan tersebut, melakukan pemasangan iklan/ pengumuman, melakukan negoisasi harga dengan calon pembeli, menghadap kepada 
pejabat yang berwenang, memberikan keteranganketerangan, menetapkan harga penjualan, memberi dan membuat kuitansi/tanda penerimaan pembayaran, menandatangani / mengajukan segala surat-surat yang diperlukan serta melakukan segala tindakan yang diperlukan untuk terlaksananya penjualan tersebut.

2.2. Menerima dan menyetorkan hasil dan penjualan benda milik pemberi kuasa sebagaimana tersebut diatas untuk pembayaran/pelunasan pinjaman sebagaimana yang tercantum dalam surat pengakuan hutang. Apabila ada sisanya, mengembalikan sisa uang hasil penjualan kepada pemberi kuasa setelah dikurangi dengan pembayaran/ pelunasan pinjaman tersebut serta segala biaya yang timbul dalam rangka penjualan.---

Selain terdapat kewajiban di dalam akta kuasa menjual juga terdapat hak didalamnya. Hak terhadap seseorang tidak dapat dihilangkan karena hak tersebut melekat dari sejak lahir sehingga untuk melaksanakan kewajibannya maka hak tersebut harus dilindungi. Analisis terhadap hak pemberi dan penerima kuasa dalam akta kuasa menjual yang tercantum dalam premis akta kuasa menjual dapat diuraikan sebagai berikut :

1. Hak Pemberi Kuasa

2. Hak Penerima Kuasa

Ad.1. Hak Pemberi Kuasa

Apabila ada sisanya, mengembalikan sisa uang hasil penjualan kepada pemberi kuasa setelah dikurangi dengan pembayaran/ pelunasan pinjaman tersebut serta segala biaya yang timbul dalam rangka penjualan.---.---.---

Berdasarkan kalimat diatas, maka dapat dinyatakan bahwa hak pemberi kuasa hanya terbatas pada sisa penjualan dari objek jaminan tersebut.Dengan demikian, apabila tidak ada sisa terhadap penjualan hak atas tanah yang dijadikan sebagai objek jaminan maka pemberi kuasa tidak menerima hasil apapun karena hasil dari penjualan tersebut telah diterima kepada penerima kuasa. Konsekuensinya pemberi kuasa kehilangan hak milik atas tanahnya dan hak atas tanahnya beralih kepada pihak ketiga.
Ad.2. Hak Penerima Kuasa

Menjual, baik secara dibawah tangan maupun dimuka umum terhadap benda milik Pemberi Kuasa yangdiserahkan kepada Penerima Kuasa sebagai agunan, atashutangnya Tuan A (bukan nama sebenarnya), lahir pada tanggal 04-04-1970 (empat april seribu sembilanratus tujuh puluh), Warga Negara Indonesia, pekerjaan Wiraswasta, bertempat tinggal di Jalan Pantai Berawa Nomor 15, BanjarPelambingan, Desa/Kelurahan Tibubeneng, KecamatanKuta Utara, Kabupaten Badung, pemegang Kartu TandaPenduduk Nomor : 5103060404700008 .

-sebagaimana dinyatakan dalam Surat Pengakuan HutangNomor : B.301/4716/5/2015, tanggal 25-052015 (duapuluh lima Mei duaribu limabelas) beserta perubahannya (selanjutnya disebut Surat Pengakuan Hutang), atas :-......-----

-Sebidang tanah sertipikat Hak Milik Nomor : 2422/Desa Canggu, Gambar Situasi tanggal 08-11-1995 (delapan Nopember seribu Sembilan ratus Sembilan puluh lima), Nomor: 4967/1995, seluas : 1150 M2 (seribu seratus lima puluh meter persegi),terletak di Desa Canggu, Kecamatan Kuta, Kabupaten Badung, satu dan lain sebagaimana yang lebih jelas diuraikan dalamsertipikat Hak Milik tersebut tertanggal 25-11-1996 (dua puluh limaNopember seribu Sembilan ratus Sembilan puluh lima) dengan perubahan terakhir tertanggal yang sama, dikeluarkan oleh yang berwenang di Badung,tertera atas nama Doktorandus B (bukan nama sebenarnya)

-berikut segala sesuatu yang telah maupun kelak didirikan dan/atau tertanam diatastanah tersebut, yang karena sifatnya, maksudnya atau menurut hukum dianggap sebagai harta tetap dan merupakan satu kesatuan dengan tanah tersebut.----

Menyimak klausul tersebut, maka hak penerima kuasa dapat diibaratkan sebagai pemilik hak atas tanah ketika pemberi kuasa mengalami wanprestasi.Penerima kuasa berhak menjual hak atas tanah tersebut seluruhnya dan hasil dari penjualan 
tersebut diberikan kepada penerima kuasa akibat dari pemberi kuasa yang wanprestasi.

\subsubsection{Tanggung Jawab Notaris terhadap Akta Kuasa Menjual yang Dibuat Dihadapannya}

Tanggung jawab Notaris di dalam UndangUndang Jabatan Notaris (UUJN) bermaksud sebagai suatu ikatan terhadap Notaris dalam menjalankan tugas dan kewajibannya sesuai dengan ketentuan yang terdapat dalam UUJN Perubahan Dalam pengertian bahwa, semua perbuatan Notaris dalam menjalankan tugas kewajibannya harus dapat dipertanggungjawabkan secara hukum, termasuk dengan segala konsekuensinya untuk dikenakan Sanksi hukum terhadap pelanggaran normanorma hukum yang mendasarinya.

Dalam menjalankan jabatannya sebagai pejabat umum, notaris memiliki tanggung jawab yang bersifat perdata, administratif dan pidana. Penjelasan mengenai tanggung jawab tersebut akan dideskripsikan sebagai berikut :

1. Tanggung Jawab Perdata

2. Tanggung Jawab Administratif

3. Tanggung Jawab Pidana

Ad.1. Tanggung Jawab Perdata.

Tanggung jawab Notaris dalam hukum perdata berupa tanggung jawab atas tindakan notaris dalam membuat akta yang dilakukan secara melawan hukum, atau notaris diduga melakukan perbuatan yang melawan hukum atas akta yang dibuatnya.Perbuatan melawan hukum memiliki ruang lingkup yang lebih luas dibandingkan dengan hukum pidana. Perbuatan melawan hukum tidak hanya mencakup perbuatan yang bertentangan dengan undang-undang pidana saja, akan tetapi jika perbuatan tersebut bertentangan dengan undang-undang lainnya dan bahkan dengan ketentuanketentuan hukum yang tidak tertulis.

Ad.2. Tanggung Jawab Administratif

Secara normatif Notaris mendapat sanksi administratif dalam pembuatan akta jika dapat dapat dibuktikan bahwa Notaris telah melakukan kesalahan seperti yang tertera dalam ketentuan UUJN Perubahan yang dapat dikenai sanksi berupa:
a. peringatan tertulis ;
b. pemberhentian sementara;
c. pemberhentian dengan hormat ; atau
d. pemberhentian dengan tidak hormat.

Kategori pelanggaran jabatan yang dilakukan oleh Notaris tidak diklasifikasikan mengenai yang mana saja yang termasuk sanksi dalam bentuk teguran tertulis, pemberhentian sementara, pemberhentian dengan hormat dan pemberhentian dengan tidak hormat.Akan tetapi, pelanggaran-pelanggaran tersebut sudah jelas tercantum dalam UUJN Perubahan walaupun tidak secara spesifik dikategorikan mengenai sanksi-sanksinya. Adapun pelanggaran-pelanggaran yang dapat dikenakan sanksi secara administratif,

Ad.3. Tanggung Jawab Pidana

Dasar untuk menetapkan adanya unsur sifat melawan hukum dalam hukum pidana dari perbuatan seorang Notaris, harus dibuktikan terlebih dahulu unsur-unsur tindak pidana dari pasal-pasal KUHP seperti pemalsuan, penipuan, penggelapan dan diluar KUHP, seperti turut serta menganjurkan atau membantu tindak pidana korupsi, pencucian uang atau kejahatan lainnya. Apabila tidak dapat dibuktikan unsur-unsur tindak pidana tersebut maka kesalahan Notaris berasal dari "standart minimum of service" yang bersumber dari peraturan jabatan Notaris, Anggaran Dasar dan Rumah Tangga Ikatan Notaris Indonesia dan juga ketentuan hukum pelaksanaan jabatan Notaris lainnya.

Notaris yang diduga terlibat dalam sebuah tindak pidana seyogyanya harus benar-benar dibuktikan keterlibatannya sebagaimana diatur dalam Pasal 55 dan 56 KUHP yang mengatur tentang penyertaan (deelnemin, domplicity) tindak pidana. Dalam Pasal 55 KUHP diatur siapasiapa yang dapat dipidana sebagai pembuat (dader) yaitu mereka yang melakukan (plager) artinya secara lengkap memenuhi unsur tindak pidana dan pelaku ini sebagai suatu bentuk tunggal; mereka yang menyuruh lakukan (doen plager) artinya menggerakan orang lain untuk melakukan tindak pidana, tetapi orang lain tersebut (dengan alasan apapun) tidak dapat dikenai pidana. Misalnya : orang yang tidak mampu bertanggung jawab karena kurang sempurna akalnya (Pasal 44 KUHP); Mereka yang turut serta melakukan (medepleger) artinya bersepakat dengan orang lain membuat rencana untuk melakukan suatu tindak pidana dan secara berssama-sama melaksanakannya (bewuste samenwerking); mereka yang menganjurkan atau membujuk 
(uitlokker) dengan bantuan salah satu upaya yang secara limitative disebut dalam Pasal 55 ayat (1) No. 2 KUHP yang disebut sarana-sarana pembujukan, membujuk orang lain untuk melakukan tindak pidana.

Selanjutnya dalam Pasal 56 KUHP diatur tentang pembantuan (medeplichtigheid), yaitu mereka yang memberikan bantuan sebelum atau pada saat tindak pidana dilakukan. Pada kasus sebelum tindak pidana dilakukan, bantuan bisa berupa memberikan kesempatan, sarana atau keterangan untuk melakukan tindak pidana. Berbeda dengan penganjuran yang juga mendayagunakan kesempatan, sarana dan keterangan, pada konteks penganjuran, si penganjur memiliki kepentingan sendiri terhadap terjandinya tindak pidana, sedangkan dalam pembantuan yang bersangkutan hanya sekedar membantu. Hal ini penting karena tindak pidana pembantuan pidananya lebih ringan daripada pidana penganjuran (maksimumnya dIkurangi sepertiga).

\section{Penutup}

\subsection{Kesimpulan}

1. Pengaturan Kuasa Menjual tidak ditemukan di dalam berbagai ketentuan peraturan perundangundangan di Indonesia. Kuasa Menjual didasarkan atas kesepakatan para pihak yang membuatnya dengan berpijak pada asas kebebasan berkontrak. Berdasarkan Pasal 1338 KUHPerdata dan Asas Praduga Keabsahan, akta Kuasa Menjual sah sepanjang tidak dibatalkan oleh hakim dengan putusan pengadilan yang mempunyai kekuatan hukum yang tetap. Penggunaan akta kuasa menjual dianggap lemah karena kuasa menjual tidak dapat dijadikan sebagai dasar untuk mengeksekusi objek jaminan antara pemberi dan penerima kuasa. Dengan demikian akta kuasa menjual dirasa belum mendapat kepastian hukum karena pada saat pendaftaran peralihan hak atas tanah kuasa menjual tidak dapat diterima oleh Kantor Pertanahan setempat.

2. Tanggung jawab pemberi dan penerima kuasa terkait dengan akta kuasa menjual yang dibuatnya berhubungan dengan kewajiban dan hak pemberi dan penerima kuasa. Sedangkan untuk tanggung jawab notaris yang membuat akta kuasa menjual dikaji dari 3 aspek, yaitu : (1). Tanggung jawab perdata; (2). Tanggung jawab administratif; dan (3). Tanggung jawab pidana. Kuasa menjual yang dibuat dihadapan notaris ini akan dipakai penerima kuasa untuk menjual hak atas tanah pemberi kuasa ketika pemberi kuasa (debitur) mengalami wanprestasi. Penerima kuasa (kreditur) berhak menjual hak atas tanah yang dijadikan sebagai objek jaminan utang piutangnya untuk melunasi sisa utangnya. Upaya hukum yang dapat ditempuh jika debitur mengalami wanprestasi dapat dilakukan dengan cara somasi terlebih dahulu tanpa menjual hak atas tanah yang dimiliki oleh pemberi kuasa (debitur).

\subsection{Saran}

1. Diharapkan kepada pembentuk peraturan perundang-undangan untuk membuat ketentuan mengenai kuasa menjual yang terkait dengan utang-piutang agar para pihak yang ingin membuat kuasa menjual beserta Notaris tidak mengalami permasalahan kedepannya terhadap akta autentik yang dibuatnya.

2. Diharapkan kepada Notaris untuk tidak membuat kuasa menjual yang berkaitan dengan utang piutang karena akta kuasa menjual tidak bermanfaat dan tidak memberikan perlindungan hukum bagi para pihak. Notaris wajib mengarahkan kepada para pihak agar dibuatkan akta Surat Kuasa Membebankan Hak Tanggungan yang sudah jelas dasar hukumnya dibandingkan membuat akta kuasa menjual.

\section{DAFTAR BACAAN}

Philipus M. Hadjon, 1983, (Bestuurshandeling) Tindak Pemerintahan : PengertianPengertian Dasar, Djumali, Surabaya

Ridwan HR, 2002, Hukum Administrasi Negara, Raja Grafindo Persada, Jakarta

Utrecht dan Moh. Saleh Djindang, 1990, Pengantar Hukum Administrasi Negara Indonesia, Ichtiar, Jakarta 